\title{
Composition and Structure of Triacylglycerol of Muscle Lipids from Laying Hen as Influenced by Dietary Fats
}

\author{
Akihiro Hirata*, Tetsuya Masuda ${ }^{*}$, Teiji Kimura* and Yoshiyuki Ohtake* \\ * College of Agriculture \& Veterinary Medicine, Nihon University, \\ 3-34-1, Shimouma, Setagaya-ku, Tokyo, 154
}

\begin{abstract}
The effects of dietary fats (soybean oil, coconut oil, lard and beef tallow) on the changes in composition and structure of triacylglycerol (TG) in muscle lipids of laying hens were studied. The fatty acid composition found in muscle total lipids from each dietary treatment group reflected the composition of fats added to the rations. The TG from thigh and breast muscle were subjected to stereospecific analysis. Generally, $\mathrm{C}_{16: 0}, \mathrm{C}_{16: 1}$, and $\mathrm{C}_{18: 0}$ were preferentially esterified at positions sn- 1 and sn-3. C18:1 tends to linked to position sn-3 more than other positions, and $\mathrm{C}_{18: 2}$ was predominated in position sn-2 of muscle TG. TG species were resolved on the basis of carbon number by high temperature gas-liquid chromatography. The muscle lipids from soybean oil, lard and tallow groups commonly comprised the TG of $\mathrm{C}_{50}, \mathrm{C}_{52}$ and $\mathrm{C}_{54}$ as the major TG components, and those from coconut oil group contained many medium chain length $\mathrm{TG}$ as $\mathrm{C}_{34} \sim \mathrm{C}_{48}$ components in addition to $\mathrm{C}_{50} \sim \mathrm{C}_{54}$. The TG was separated into simpler molecular species according to the degree of unsaturation by argentation thin-layer chromatography $\left(\mathrm{AgNO}_{3}-\mathrm{TLC}\right)$. The lipids from soybean oil group contained less $\mathrm{S}_{2} \mathrm{M}$ and $\mathrm{SM}_{2}$ and more of $\mathrm{M}_{2} \mathrm{D}, \mathrm{SD}_{2}, \mathrm{MD}_{2}$, SMT and $\mathrm{D}_{3}$ species than the other groups, while the lipids from coconut oil group had the highest level of $\mathrm{S}_{3}$ and $\mathrm{S}_{2} \mathrm{M}$ species among the dietary groups. The experimentally determined values of $\mathrm{TG}$ species were compared with the values predicted assuming a 1-random, 2-random, 3-random arrangement of fatty acids in intact TG. The agreement was considerably good for muscle TG from lard and tallow groups, but some discrepancies were observed for TG from soybean oil and coconut oil groups. This suggests that in laying hen there is preferential synthesis of some TG species influenced by ingested dietary fatty acids.
\end{abstract}

The fatty acid composition of tissues of chicken has been studied by a number of researchers ${ }^{1)-5)}$, and considerable information has been reported concerning the influence of dietary fats on fatty acid composition of lipids in chicken tissues $^{6 \sim 11)}$. The fatty acid composition of body fat in animals is generally a reflection of the dietary fatty acid pattern. The degree of unsaturation of fatty acids in chicken tissues is influenced by the degree of unsaturated fatty acids in diet and tends to assume the fatty acid composition of the diet ${ }^{73}$. The nature, proportion, and degree of unsaturated fatty acids present in lipid will indicate the approximate susceptibility of lipid towards oxidative deterioration ${ }^{4}$. The fatty acid com- position of body fats is primarily influenced by dietary fatty acids and results from highly specific and controlled metabolic reactions which concern not only the influence of one fatty acid on the distribution of other fatty acids, but also the position of the fatty acids on the glycerol molecule ${ }^{12)}$. In addition to gross fatty acid composition, the distribution of fatty acids among three positions of Lglycerol is an important factor in determining the physical properties of muscle tissues $\mathrm{TG}^{13)}$. There have been many reports on the effects of different dietary treatments upon the gross fatty acid compositions of TG in chicken muscle tissue, but there is few information available on the effects of dietary fatty acids upon 
the structure of tissue TG. This investigation is designed to elucidate the comparative effects of different dietary fats on the composition and molecular structure of muscle lipids from laying hens fed fat-supplemented diets.

\section{Materials and Methods}

Treatment of the birds and muscle samples Twenty laying White Leghorn hens, 8 to 10 months of age, were divided into four groups of five each, and each group was given one of the experimental diet ad libitum for a period of 50 days. The composition of rations and fatty acid compositions of dietary fats described previously ${ }^{14)}$ are shown in Table 1.

After 50 days feeding on the experimental diets, hens were fasted overnight, sacrificed, and the thigh and breast muscles were removed from carcasses for analysis. These muscle were freed of skin and visible fatty tissue and kept at $-15^{\circ} \mathrm{C}$ until analyses were carried out.

Extraction of lipids and preparation of triacylglycerol

The muscle samples were minced by a home meat chopper with a plate of $3 \mathrm{~mm}$ pores. The total lipids were extracted from each minced meat sample according to the method of $\mathrm{FoLCH}$ et $a l^{15)}$, and were separated into neutral and polar lipid fractions by the procedure of MoERCK and BALL ${ }^{16)}$. Then, TG was isolated from each neutral lipid fraction by Unicil (Clarkson Chem. Co.) silisic acid column chromatography as described by MoERck and BALL ${ }^{16)}$.

\section{Streospecific analysis}

The fatty acid composition of each of three

Table 1 Composition of experimental diet and fatty acid compositions of supplemented fat or oil to the experimental diets

\begin{tabular}{lc}
\hline \multicolumn{1}{c}{ Ingredient } & Content (wt, \%) \\
\hline Corn starch & 34.549 \\
Soybean oil meal & 45 \\
Fat (oil) & 10 \\
Salt (NaCl) & 0.5 \\
Calcium carbonate & 6 \\
Dicalcium phosphate & 3.2 \\
DL-Methionine & 0.25 \\
Vitamin premix & 0.3 \\
Trace mineral premix & 0.2 \\
Carophyll*** & 0.001 \\
\hline
\end{tabular}

* Supplied amounts per $\mathrm{kg}$ of diet: Vitamin A, 15000 I. U. ; Vitamin $D_{2} 2000$ I. U. ; Vitamin E, 20 I.U.; Vitamin $\mathrm{K}_{3}, 5 \mathrm{mg}$; Thiamin hydrochloride, 10 I. U. ; Riboflavin, 10 $\mathrm{mg}$; Calcium pantotheanate, $10 \mathrm{mg}$; Nicotinamide, $5 \mathrm{mg}$; Folic acid, $5 \mathrm{mg}$; Pyridoxine hydrochloride, $5 \mathrm{mg}$; Biotin, $0.5 \mathrm{mg}$; Vitamin $B_{12}, 0.02 \mathrm{mg}$; Inositol, $100 \mathrm{mg}$; Calcium ascorbate, $250 \mathrm{mg}$; Cholin chloride, $1000 \mathrm{mg}$

** Supplied amounts per kg of diet: $\mathrm{MnCO}_{3}$, $150 \mathrm{mg} ; \mathrm{Fe}$-citrate, $100 \mathrm{mg} ; \mathrm{Na}_{2} \mathrm{SeO}_{4} \cdot 10 \mathrm{H}_{2} \mathrm{O}$, $0.5 \mathrm{mg} ; \mathrm{H}_{3} \mathrm{BO}_{4}, 1 \mathrm{mg} ; \mathrm{Zn}$-acetate, $50 \mathrm{mg}$; $\mathrm{Na}_{2} \mathrm{MoO}_{4} \cdot 2 \mathrm{H}_{2} \mathrm{O}, 5 \mathrm{mg} ; \mathrm{KIO}_{3}, 0.5 \mathrm{mg} ; 2 \mathrm{Co}$ $\left(\mathrm{OH}_{2}\right) \cdot \mathrm{H}_{2} \mathrm{O}, 0.5 \mathrm{mg}$ ***Feed pigment (Roche)

\begin{tabular}{|c|c|c|c|c|}
\hline & $\begin{array}{c}\text { Soybean } \\
\text { oil }\end{array}$ & $\begin{array}{l}\text { Coconut } \\
\text { oil }\end{array}$ & Lard & Tallow \\
\hline Fatty acid* & & (wt. 96 & & \\
\hline $8: 0$ & & 7.3 & & \\
\hline $10: 0$ & & 6.2 & & \\
\hline $12: 0$ & & 47.3 & $\operatorname{tr}$ & $\operatorname{tr} * *$ \\
\hline $14: 0$ & $\operatorname{tr}$ & 18.9 & 1.5 & 3.1 \\
\hline $14: 1$ & $\operatorname{tr}$ & & 0.2 & 0.8 \\
\hline $15: 0$ & $\operatorname{tr}$ & & 0.1 & 0.4 \\
\hline $16: 0 \mathrm{Br}$ & & & & 0.1 \\
\hline $16: 0$ & 10.6 & 9.4 & 24.3 & 24.3 \\
\hline $16: 1$ & & & 3.4 & 2.9 \\
\hline $17: 0$ & & & & 0.9 \\
\hline $17: 0 \mathrm{Br}$ & 0.1 & & 0.4 & 1.2 \\
\hline $17: 1$ & & & 0.3 & 0.6 \\
\hline $18: 0$ & 3.8 & 2.8 & 12.5 & 18.8 \\
\hline $18: 1$ & 22.5 & 6.5 & 44.7 & 42.1 \\
\hline $18: 2$ & 54.1 & 1.5 & 10.7 & 3.7 \\
\hline $18: 3$ & 8.6 & & 0.7 & 0.5 \\
\hline $20: 1$ & 0.3 & & 1.1 & 0.7 \\
\hline Sat. acid & 14.5 & 91.9 & 38.8 & 48.8 \\
\hline Unsat. acid & 85.5 & 8.1 & 61.2 & 51.2 \\
\hline
\end{tabular}

* Number of carbon atom : number of double bond, $\mathrm{Br}=$ branched chain acid

** $\operatorname{tr}=$ trace (bellow 0.19) 
positions of the sn-glycerol moiety was determined by a streospecific analysis procedure based on that devised by BROCKERHOFF ${ }^{17)}$ and modified by CHRISTIE and MOORE ${ }^{18)}$. The scheme of analysis was briefly described previously $^{19)}$.

\section{Argentation thin-layer chromatography}

Each TG sample was separated into simpler molecular species on the basis of total number and distribution of double bonds per molecule by argentation thin-layer chromatography $\left(\mathrm{AgNO}_{3}-\mathrm{TLC}\right)$. Separation of $\mathrm{TG}$ was performed on $\mathrm{AgNO}_{3}$ implegnated Silica Gel G plate prepared by the method of Wood and Snyder $^{20)}$, using hexane-diethyl etherbenzene-methanol (70:10:20:1, by volume) as the developing solvent ${ }^{21)}$. The amount of each TG fraction separated on chromatogram was calculated with reference to the methyl heptadecanoate added as the internal standard, and the TG composition of those bands was calculated on the basis of their fatty acid composition, as described previously ${ }^{22)}$.

Gas-liquid chromatography (GLC)

Direct gas-liquid chromatography of TG was carried out on Hitachi Model-163 Gas Chromatograph. The operating conditions of GLC and determinating procedure of distribution of various TG types were as same as described previously ${ }^{19)}$. Distributions of various TG types by carbon number in muscle lipids were estimated by the method described by KuKsis et al. ${ }^{23)}$

The fatty acid composition of lipid was determined by the procedure described previous$\mathrm{ly}^{24)}$, using Shimadzu GC-6 A MPE Gas Chro-

Table 2 Fatty acid composition of muscle total lipids of laying hens fed fat-supplemented diets

(wt. \%)

\begin{tabular}{|c|c|c|c|c|c|c|c|c|}
\hline \multirow{2}{*}{ Fatty acid* } & \multicolumn{4}{|c|}{ Thigh muscle } & \multicolumn{4}{|c|}{ Breast muscle } \\
\hline & $\mathrm{SO}^{* *}$ & $\mathrm{CO}^{* *}$ & $\mathrm{~L}^{* *}$ & $\mathrm{~B}^{* *}$ & $\mathrm{SO}^{* *}$ & $\mathrm{CO}^{* *}$ & $\mathrm{~L}^{* *}$ & $\mathrm{~B}^{* *}$ \\
\hline $10: 0$ & & 0.2 & & & & 0.3 & & \\
\hline $12: 0$ & 0.3 & 12.0 & 0.1 & 0.2 & 0.4 & 10.4 & 0.1 & 0.4 \\
\hline $14: 0$ & 0.8 & 7.9 & 1.1 & 1.5 & 0.8 & 5.9 & 1.0 & 1.3 \\
\hline $14: 1$ & $\operatorname{tr}^{* * *}$ & 0.6 & 0.2 & 0.3 & $\operatorname{tr}$ & 0.3 & $\operatorname{tr}$ & 0.2 \\
\hline $15: 0$ & 0.1 & $\operatorname{tr}$ & 0.1 & 0.2 & tr & $\operatorname{tr}$ & $\mathrm{tr}$ & 0.1 \\
\hline $16: 0$ & 18.4 & 18.2 & 21.4 & 22.0 & 19.5 & 21.2 & 23.9 & 23.4 \\
\hline $16: 1$ & 3.4 & 3.5 & 4.4 & 4.2 & 2.2 & 2.4 & 3.1 & 2.8 \\
\hline $17: 0$ & 0.5 & 0.2 & 0.4 & 0.5 & 0.3 & 0.1 & 0.3 & 0.3 \\
\hline $17: 1$ & 0.1 & & & 0.3 & & & 0.1 & 0.1 \\
\hline $18: 0$ & 6.7 & 7.2 & 8.9 & 10.2 & 6.8 & 7.4 & 8.2 & 9.2 \\
\hline $18: 1$ & 36.1 & 31.9 & 44.0 & 43.2 & 33.4 & 29.2 & 40.9 & 39.5 \\
\hline $18: 2$ & 29.3 & 15.2 & 15.9 & 13.9 & 29.7 & 15.1 & 15.4 & 14.5 \\
\hline $18: 3$ & 2.2 & 0.5 & 0.5 & 0.6 & 2.1 & 0.4 & 0.5 & 0.5 \\
\hline $20: 1$ & 0.6 & 0.5 & 0.6 & 0.6 & 0.4 & 0.3 & 0.5 & 0.5 \\
\hline $20: 2$ & 0.3 & 0.2 & 0.2 & 0.2 & 0.1 & & 0.1 & \\
\hline $20: 3$ & $\operatorname{tr}$ & $\operatorname{tr}$ & $\operatorname{tr}$ & $\operatorname{tr}$ & 0.1 & 0.2 & 0.2 & 0.2 \\
\hline $20: 4$ & 1.0 & 1.6 & 1.6 & 1.8 & 2.9 & 4.6 & 3.9 & 4.9 \\
\hline $22: 4$ & & tr & 0.1 & & & 0.3 & 0.1 & 0.1 \\
\hline $22: 5$ & & $\operatorname{tr}$ & 0.1 & & 0.2 & 0.3 & 0.3 & 0.4 \\
\hline $22: 6$ & 0.2 & 0.2 & 0.3 & 0.2 & 1.0 & 1.5 & 1.3 & 1.4 \\
\hline
\end{tabular}

${ }^{*}$ Number of carbon atoms : Number of double bonds

${ }^{* *} \mathrm{SO}=$ soybean oil, $\mathrm{CO}=$ coconut oil, $\mathrm{L}=$ lard and $\mathrm{B}=$ beef tallow feeding

*** $\operatorname{tr}=$ trace (below 0.196 ) 
matograph and Shimadzu Chromatopac C-R $2 \mathrm{~A}$.

\section{Results and Discussion}

Effects of dietary fats on the fatty acid composition of muscle lipids of laying hen

The fatty acid compositions of total lipids obtained from thigh and breast muscles of laying hens fed diets supplemented with $10 \%$ of

Table 3 Positional distribution of fatty acids in triacylglycerols of chicken muscle lipids from hens fed fat-supplemented diets (mole \%)

\begin{tabular}{|c|c|c|c|c|c|c|c|c|c|c|c|}
\hline Treatment & Position* & $12: 0$ & $14: 0$ & $16: 0$ & $16: 1$ & 18:0 & $18: 1$ & $18: 2$ & Others ${ }^{* * *}$ & $\begin{array}{l}\text { Sat. } \\
\text { acid }\end{array}$ & $\begin{array}{l}\text { Unsat. } \\
\text { acid }\end{array}$ \\
\hline Thigh & muscle & & & & & & & & & & \\
\hline \multirow[t]{4}{*}{ Soybean oil } & $\mathrm{TG}^{* *}$ & 0.4 & 1.0 & 19.8 & 3.5 & 5.9 & 37.9 & 28.2 & 3.3 & 27.6 & 72.4 \\
\hline & 1 & 0.9 & 1.6 & 28.4 & 5.4 & 8.3 & 36.8 & 16.2 & 2.4 & 39.8 & 60.2 \\
\hline & 2 & 0.4 & 1.0 & 12.9 & 2.3 & 3.2 & 34.8 & 41.9 & 3.5 & 17.9 & 82.0 \\
\hline & 3 & & 0.4 & 18.1 & 2.8 & 6.2 & 42.1 & 26.5 & 3.9 & 25.2 & 75.0 \\
\hline \multirow[t]{4}{*}{ Coconut oil } & TG & 18.5 & 9.8 & 17.9 & 3.9 & 4.8 & 29.6 & 12.4 & 3.1 & 52.1 & 47.9 \\
\hline & 1 & 16.2 & 10.8 & 21.3 & 4.8 & 6.6 & 27.8 & 10.6 & 1.9 & 55.4 & 44.6 \\
\hline & 2 & 14.0 & 9.1 & 13.9 & 2.9 & 3.2 & 31.1 & 23.2 & 2.6 & 40.6 & 59.4 \\
\hline & 3 & 25.3 & 9.5 & 18.5 & 4.0 & 4.6 & 29.9 & 3.4 & 4.8 & 60.2 & 39.8 \\
\hline \multirow[t]{4}{*}{ Lard } & $\mathrm{TG}$ & 0.3 & 1.4 & 23.3 & 5.2 & 6.7 & 45.9 & 15.0 & 2.2 & 32.2 & 67.8 \\
\hline & 1 & 0.4 & 1.4 & 24.4 & 6.3 & 8.4 & 42.4 & 12.1 & 4.6 & 35.5 & 64.5 \\
\hline & 2 & 0.3 & 1.6 & 19.6 & 3.3 & 3.9 & 43.4 & 25.9 & 2.0 & 26.0 & 74.0 \\
\hline & 3 & 0.2 & 1.2 & 25.9 & 6.0 & 7.8 & 51.9 & 7.0 & 0.0 & 35.1 & 64.8 \\
\hline \multirow[t]{4}{*}{ Beef tallow } & TG & 0.4 & 2.1 & 23.9 & 5.0 & 8.1 & 44.5 & 13.2 & 2.8 & 35.3 & 64.7 \\
\hline & 1 & & 2.3 & 25.5 & 5.2 & 8.9 & 40.4 & 13.8 & 3.9 & 37.5 & 62.5 \\
\hline & 2 & 0.3 & 2.3 & 19.3 & 3.2 & 5.5 & 44.1 & 22.5 & 2.8 & 28.1 & 71.9 \\
\hline & 3 & 0.9 & 1.7 & 26.9 & 6.6 & 9.9 & 49.0 & 3.3 & 1.7 & 40.3 & 59.8 \\
\hline Breast & muscle & & & & & & & & & & \\
\hline \multirow[t]{4}{*}{ Soybean oil } & $\mathrm{TG}$ & 0.5 & 1.0 & 19.1 & 2.8 & 5.8 & 36.3 & 30.7 & 3.8 & 26.8 & 73.2 \\
\hline & 1 & 0.5 & 1.1 & 24.3 & 3.3. & 8.4 & 31.2 & 23.6 & 7.6 & 34.9 & 65.1 \\
\hline & 2 & 0.7 & 1.1 & 14.4 & 2.2 & 3.3 & 32.4 & 42.1 & 3.8 & 20.2 & 79.8 \\
\hline & 3 & 0.3 & 0.8 & 18.6 & 2.9 & 5.7 & 45.3 & 26.4 & 0.1 & 25.4 & 74.6 \\
\hline \multirow[t]{4}{*}{ Coconut oil } & $\mathrm{TG}$ & 15.6 & 8.5 & 19.7 & 3.5 & 5.7 & 31.1 & 12.9 & 3.0 & 50.4 & 49.6 \\
\hline & 1 & 13.1 & 9.3 & 23.3 & 4.2 & 7.6 & 28.7 & 9.9 & 3.9 & 54.1 & 45.9 \\
\hline & 2 & 12.5 & 7.4 & 16.2 & 2.7 & 3.4 & 32.1 & 23.2 & 2.5 & 40.0 & 60.0 \\
\hline & 3 & 21.2 & 8.8 & 19.6 & 3.6 & 6.1 & 32.5 & 5.6 & 2.6 & 57.1 & 42.9 \\
\hline \multirow[t]{4}{*}{ Lard } & $\mathrm{TG}$ & 0.3 & 1.4 & 24.5 & 4.2 & 7.4 & 44.9 & 15.2 & 2.1 & 34.0 & 66.0 \\
\hline & 1 & 0.3 & 1.5 & 27.0 & 4.9 & 9.9 & 40.7 & 12.1 & 3.5 & 39.2 & 60.9 \\
\hline & 2 & 1.0 & 1.8 & 21.0 & 3.4 & 4.0 & 40.6 & 25.9 & 2.3 & 28.6 & 71.4 \\
\hline & 3 & & 0.9 & 25.5 & 4.3 & 8.3 & 53.4 & 7.6 & 0.0 & 34.4 & 65.5 \\
\hline \multirow[t]{4}{*}{ Beef tallow } & TG & 0.8 & 2.1 & 23.9 & 4.0 & 8.3 & 43.9 & 14.3 & 2.7 & 35.8 & 64.2 \\
\hline & 1 & & 2.3 & 25.7 & 4.7 & 9.6 & 37.5 & 16.9 & 3.3 & 38.9 & 61.1 \\
\hline & 2 & 0.4 & 2.3 & 19.2 & 2.9 & 5.5 & 42.7 & 24.1 & 2.9 & 28.2 & 71.8 \\
\hline & 3 & 2.0 & 1.7 & 26.8 & 4.4 & 9.8 & 51.5 & 1.9 & 1.9 & 40.3 & 59.8 \\
\hline
\end{tabular}

* Stereospecific number in triacylglycerol

** $\mathrm{TG}=$ Original triacylglycerol

*** Contained 10:0,14:1, 15:0,17:0 $\mathrm{Br}, 17: 0,17: 1,18: 3$ and 20:1 fatty acid

Other abbreviations used are the same as those described in Table 1. 
soybean oil, coconut oil, lard or beef tallow are presented in Table 2.

Fatty acid composition of breast muscle lipid was similar to that of thigh muscle lipid in each dietary group, although the breast muscle lipid contained a little less oleic acid $\left(\mathrm{C}_{18: 1}\right)$ and more arachidonic acid $\left(\mathrm{C}_{20: 4}\right)$ than the thigh muscle lipids in each corresponding dietary treatment group.

As shown in Table 2, the muscle lipid from hens fed soybean oil-supplemented diet (soybean oil group) had more linoleic acid ( $\left.\mathrm{C}_{18: 2}\right)$ and linolenic acid $\left(\mathrm{C}_{18: 3}\right)$ than those from the other dietary groups. The muscle lipids from hens fed coconut oil-supplemented diet (coconut oil group) and from soybean oil group had less $C_{18: 1}$ than those from lard or beef tallow feeding groups (lard group or tallow group). The lipids of coconut oil group contained considerably large amount of lauric acid $\left(\mathrm{C}_{12: 0}\right)$ and myristic acid $\left(\mathrm{C}_{14: 0}\right)$ compared with those of other dietary groups. Fatty acid compositions of the thigh and breast muscle lipids from lard group were rather similar to that from the tallow group in each muscle. In general, the fatty acid composition in each dietary group reflected the fatty acid patterns of fats supplemented to the feeds.

The results of this study on coconut oil feeding to hens agreed with the changes in fatty acid compositions of chicken muscle lipids observed by MARION et $a ._{.}{ }^{25)}$, and the results on beef tallow feeding resembled to that reported by SCHULER and ESSARY ${ }^{7}$. The

Table 4 Proportional distributions of fatty acids on each position in a triacylglycerol of chicken muscle lipids

(\%)

\begin{tabular}{|c|c|c|c|c|c|c|c|c|c|c|c|c|}
\hline \multirow{3}{*}{$\frac{\text { Treatment }}{\text { Position }}$} & \multicolumn{12}{|c|}{ Thigh muscle } \\
\hline & \multicolumn{3}{|c|}{$\mathrm{SO}$} & \multicolumn{3}{|c|}{$\mathrm{CO}$} & \multicolumn{3}{|c|}{$\mathrm{L}$} & \multicolumn{3}{|c|}{$B$} \\
\hline & 1 & 2 & 3 & 1 & 2 & 3 & 1 & 2 & 3 & 1 & 2 & 3 \\
\hline $12: 0$ & 69 & 31 & & 29 & 25 & 46 & 44 & 33 & 22 & & 25 & 75 \\
\hline $14: 0$ & 53 & 33 & 13 & 37 & 31 & 32 & 33 & 38 & 29 & 37 & 37 & 27 \\
\hline $16: 0$ & 48 & 22 & 30 & 40 & 26 & 34 & 35 & 28 & 37 & 36 & 27 & 38 \\
\hline $16: 1$ & 51 & 22 & 27 & 41 & 25 & 34 & 40 & 21 & 38 & 35 & 21 & 44 \\
\hline $18: 0$ & 47 & 18 & 35 & 46 & 22 & 32 & 42 & 19 & 39 & 37 & 23 & 41 \\
\hline $18: 1$ & 32 & 31 & 37 & 31 & 35 & 34 & 31 & 32 & 38 & 30 & 33 & 37 \\
\hline $18: 2$ & 19 & 50 & 31 & 28 & 62 & 9 & 27 & 58 & 16 & 35 & 57 & 8 \\
\hline Sat. acid & 48 & 22 & 30 & 35 & 26 & 39 & 37 & 27 & 36 & 35 & 27 & 38 \\
\hline \multirow[t]{2}{*}{ Unsat. acid } & 28 & 38 & 34 & 31 & 41 & 28 & 32 & 36 & 32 & 32 & 37 & 31 \\
\hline & \multicolumn{12}{|c|}{ Breast muscle } \\
\hline Treatment & \multicolumn{3}{|c|}{$\mathrm{SO}$} & \multicolumn{3}{|c|}{$\mathrm{CO}$} & \multicolumn{3}{|c|}{$\mathrm{L}$} & \multicolumn{3}{|c|}{$\mathrm{B}$} \\
\hline Position & 1 & 2 & 3 & 1 & 2 & 3 & 1 & 2 & 3 & 1 & 2 & 3 \\
\hline $12: 0$ & 32 & 47 & 20 & 28 & 27 & 45 & 23 & 77 & & & 17 & 83 \\
\hline $14: 0$ & 37 & 37 & 27 & 36 & 29 & 35 & 36 & 43 & 21 & 37 & 37 & 27 \\
\hline $16: 0$ & 42 & 25 & 32 & 39 & 27 & 33 & 37 & 29 & 35 & 36 & 27 & 37 \\
\hline $16: 1$ & 39 & 26 & 35 & 40 & 26 & 34 & 39 & 27 & 34 & 39 & 24 & 37 \\
\hline $18: 0$ & 48 & 19 & 33 & 44 & 20 & 36 & 45 & 18 & 37 & 39 & 22 & 39 \\
\hline $18: 1$ & 29 & 30 & 42 & 31 & 34 & 35 & 30 & 30 & 40 & 28 & 32 & 39 \\
\hline $18: 2$ & 26 & 46 & 29 & 26 & 60 & 14 & 27 & 57 & 17 & 39 & 56 & 4 \\
\hline Sat. acid & 43 & 25 & 32 & 36 & 26 & 38 & 38 & 28 & 34 & 36 & 26 & 38 \\
\hline Unsat. acid & 30 & 36 & 34 & 31 & 40 & 29 & 31 & 36 & 33 & 32 & 37 & 31 \\
\hline
\end{tabular}

Abbreviations used are the same as those described in Table 1. 
results on soybean oil feeding in this study were similar to the results on feeding of corn oil to hens studied by CHUNG et al. ${ }^{8)}$; this was probably due to the similar fatty acid pattern of soybean oil to that of corn oil.

Effects of dietary fats on the fatty acid distribution in TG of muscle lipids of laying hen

The TG of thigh and breast muscle lipids were subjected to stereospecific analyses to investigate the distribution of fatty acids in positions sn-1, sn-2, and sn-3 of TG molecule. The fatty acid composition of original $T G$ and of the three positions of the sn-glycerol moiety are given in Table 3.

In TG of the thigh and breast muscle lipids from hens of all groups, palmitic acid ( $\left.\mathrm{C}_{16: 0}\right)$,

Table 5 Triacylglycerol compositions of chicken muscle lipids (mole \%)

\begin{tabular}{|c|c|c|c|c|}
\hline \multirow{2}{*}{ TG type* } & \multicolumn{4}{|c|}{ Thigh muscle } \\
\hline & $\mathrm{SO}$ & $\mathrm{CO}$ & L & $\mathrm{B}$ \\
\hline sn-SSS & 1.8 & 13.5 & 3.2 & 4.2 \\
\hline sn-SSU & 5.3 & 9.0 & 6.0 & 6.4 \\
\hline sn-SUS & 8.2 & 19.8 & 9.2 & 10.9 \\
\hline sn-USS & 2.7 & 10.9 & 5.9 & 7.1 \\
\hline sn-SUU & 24.5 & 13.1 & 17.1 & 16.3 \\
\hline sn-USU & 8.1 & 7.2 & 11.0 & 10.6 \\
\hline sn-UUS & 12.4 & 15.9 & 16.8 & 18.1 \\
\hline sn-UUU & 37.0 & 10.5 & 31.2 & 27.1 \\
\hline \multirow{2}{*}{ TG type* } & \multicolumn{4}{|c|}{ Breast muscle } \\
\hline & SO & $\mathrm{CO}$ & $\mathrm{L}$ & $\mathrm{B}$ \\
\hline sn-SSS & 1.8 & 12.4 & 3.9 & 4.4 \\
\hline sn-SSU & 5.3 & 9.5 & 7.4 & 6.6 \\
\hline sn-SUS & 7.1 & 18.5 & 9.8 & 11.3 \\
\hline sn-USS & 3.3 & 10.5 & 6.1 & 6.9 \\
\hline sn-SUU & 21.0 & 14.2 & 18.6 & 16.7 \\
\hline sn-USU & 9.9 & 8.1 & 11.6 & 10.3 \\
\hline sn-UUS & 13.2 & 15.7 & 15.2 & 17.7 \\
\hline sn-UUU & 39.1 & 12.1 & 28.9 & 26.2 \\
\hline
\end{tabular}

* Calculated triacylglycerol type by means of 1-random, 2-random, 3-random distribution. an- : stereospecifically numbered.

$\mathrm{S}$ : Saturated, U : unsaturated fatty acid.

Other abbreviations used are the same as those described in Table 1. palmitoleic acid $\left(\mathrm{C}_{16: 1}\right)$ and stearic acid $\left(\mathrm{C}_{18: 0}\right)$ were preferentially esterified in position sn-1 and sn-3. C18:1 was generally predominant at position sn- 3 excepting in the thigh muscle TG of coconut oil group. Position sn-2 of muscle $\mathrm{TG}$, in both thigh and breast, was preferen tially occupied by $\mathrm{C}_{18: 2}$. Concerning the shorter chain fatty acids of muscle TG from hens fed coconut oil, $\mathrm{C}_{12: 0}$ was esterified predominantly in position $\mathrm{sn}-3$, whereas $\mathrm{C}_{14: 0}$ was distributed comparatively evenly into three positions of TG molecule. In all, saturated fatty acids were found more in positions sn-1 and sn- 3 than in position sn-2, and unsaturated fatty acids were present in abundance in position sn-2 of chicken muscle TG.

The proportional distributions of fatty acids among three positions in the muscle TG are shown in Table 4.

Proportional distribution patterns of every fatty acids, excepting $\mathrm{C}_{12: 0}$ and $\mathrm{C}_{18: 2}$, were comparatively similar in both thigh and breast
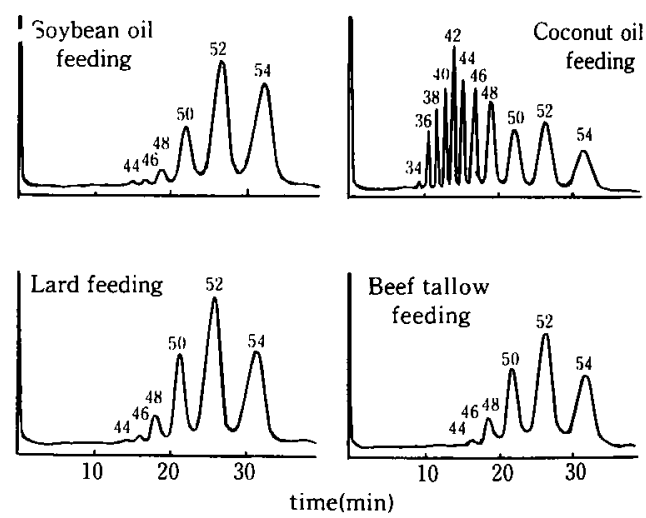

Fig. 1 GLC separation of triacylglycerols of thigh muscle from laying hens fed fat-supplemented diets. Figures of peaks represent the total number of acyl carbon atoms.

Hitachi Model-163 Gas Chromatograph; Column, 2\% Silicon SE-30 on 80-100 mesh Chromosorb WAW; injection and detector's temperature, $330^{\circ} \mathrm{C}$; temperature programmed at $7.5^{\circ} \mathrm{C} / \mathrm{min}$ over the range of $200 \sim 300^{\circ} \mathrm{C}$. 
muscle TG regardless of different dietary treatments. Although, feeding of soybean oil to hen increased the proportion of $\mathrm{C}_{18: 2}$ distributed in $\mathrm{sn}-3$ position of muscle $\mathrm{TG}$, predominant distribution of $\mathrm{C}_{18: 2}$ in sn-2 position of $\mathrm{TG}$ was common to the muscle TG from all dietary groups. This suggests that the species specificity of positional distribution of main fatty acids in chicken muscle TG is not affected by dietary fats fed to hens.

Effects of dietary treatments of laying hen on the composition and types of muscle $T G$

The amounts of each TG type in lipid could be calculated from the known fatty acid composition in intact $\mathrm{TG}$ assuming a 1random, 2-random, 3-random arrangement. The results obtained on the thigh and breast muscle TG from each dietary group are given in Table 5.

The proportions of TG types of the thigh muscle lipids were similar to that of the breast muscle lipids in each corresponding dietary group. The most abundant TG type in lipids from soybean oil, lard and tallow groups was triunsaturated TG (sn-UUU), followed by monosaturated diunsaturated TG of sn-SUU or sn-UUS, and the least TG was trisaturated TG
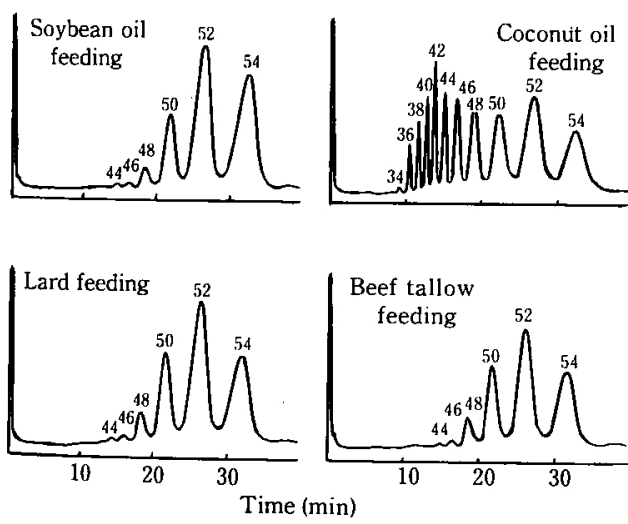

Fig. 2 GLC separation of triacylglycerols of breast muscle from laying hens fed fat-supplemented diets

Figures of peaks represent the total number of acyl carbon atoms. Instrument and operating conditions are the same as the footnote in Fig. 1.
(sn-SSS). In contrast to this, the major component TG types of coconut oil group were sn-SUS, sn-UUS, sn-SUU and sn-SSS, and the lipid of coconut oil group contained the least of sn-UUU among all dietary groups. Muscle lipids from lard group had similar proportions of TG composition to that from tallow group.

Effects of dietary treatments of laying hen on the muscle TG species based on carbon number

The TG was separated into simpler molecular species by high temperature gas-liquid chromatography according to the total number of acyl carbon atoms of TG. The GLC elution patterns for the thigh and breast muscle TG of laying hen from each group are shown in Fig. 1 and 2 .

The elution patterns for TG of the thigh muscle lipids from each dietary group were similar to those of breast muscle lipids from corresponding dietary group, respectively. The chromatograms for the muscle TG from soy-

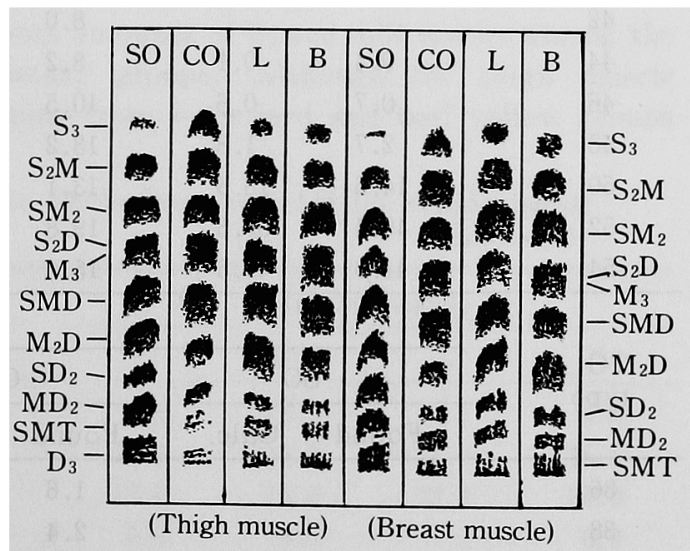

Fig. 3 Argentation thin-layer chromatograms of triacylglycerols of muscle lipids from hens fed fat-supplemented diets

Plate: Silica Gel G impregnated 10\% $\mathrm{AgNO}_{3}$. Developing solvent system : hexane-ethyl ether-benzen-methanol (70/10/20/ 1 , by volume). SO, $\mathrm{CO}, \mathrm{L}$ and $\mathrm{B}$ are soybean oil, coconut oil, lard and beef tallow feeding groups, respectively. $\mathrm{S}=$ Saturated, $\mathrm{M}=$ monoenoic, $\mathrm{D}=$ dienoic and $\mathrm{T}=$ trienoic fatty acid moieties. 
bean oil, lard and beef tallow groups showed commonly the presence of the TG with acyl carbon number 50,52 and $54\left(\mathrm{C}_{50}, \mathrm{C}_{52}\right.$ and $\left.\mathrm{C}_{54}\right)$ as the major TG components, and concomitant minor TG species of $\mathrm{C}_{44}, \mathrm{C}_{46}$ and $\mathrm{C}_{48}$. On the contrary, the GLC elution patterns of both thigh and breast muscle lipids from coconut oil group, showed the presence of many peaks of medium chain length $\mathrm{TG}$ species of $\mathrm{C}_{34} \sim \mathrm{C}_{48}$ in addition to the $\mathrm{C}_{50} \sim \mathrm{C}_{54}$.

Distributions of TG types specified by carbon number in the thigh and breast muscle lipids determined by GLC are given in Table 6 . Added to the determined values of $\mathrm{TG}$, the predicted values which were calculated by the positional distribution of fatty acids assuming a 1-random, 2-random, 3-random arrangement are given in Table 6.

The observed and also the predicted values of TG of the thigh muscle lipids from each dietary group were similar to those of breast muscle lipids from corresponding group, respectively. The comparison between the findings by GLC resolution and that by calculation based on

Table 6 Composition of observed and predicted values of triacylglycerols of chioken muscle lipids (wt. \%)

\begin{tabular}{|c|c|c|c|c|c|c|c|c|}
\hline \multirow{3}{*}{$\begin{array}{l}\mathrm{TG}^{* * *} \\
\text { type }\end{array}$} & \multicolumn{8}{|c|}{ Thigh muscle } \\
\hline & \multicolumn{2}{|c|}{ SO } & \multicolumn{2}{|c|}{$\mathrm{CO}$} & \multicolumn{2}{|c|}{$\mathrm{L}$} & \multicolumn{2}{|c|}{ B } \\
\hline & Found* & Calc. ${ }^{* *}$ & Found & Calc. & Found & Calc. & Found & Calc. \\
\hline 36 & & & 2.7 & 0.6 & & & & \\
\hline 38 & & & 3.6 & 1.2 & & & & \\
\hline 40 & & & 5.0 & 2.1 & & & & \\
\hline 42 & & & 8.0 & 5.5 & & & & \\
\hline 44 & 0.4 & 0.1 & 8.2 & 9.6 & 0.4 & 0.1 & 0.2 & 0.2 \\
\hline 46 & 0.7 & 0.6 & 10.5 & 15.3 & 0.9 & 0.8 & 1.0 & 1.2 \\
\hline 48 & 2.7 & 1.8 & 13.2 & 20.6 & 4.5 & 4.5 & 5.5 & 5.8 \\
\hline 50 & 14.6 & 13.5 & 13.1 & 14.2 & 19.1 & 18.9 & 20.6 & 20.0 \\
\hline 52 & 40.4 & 39.6 & 19.8 & 15.0 & 41.8 & 40.2 & 41.2 & 38.8 \\
\hline \multirow[t]{2}{*}{54} & 41.0 & 40.5 & 15.6 & 10.5 & 33.4 & 32.6 & 31.6 & 29.7 \\
\hline & \multicolumn{8}{|c|}{ Breast muscle } \\
\hline \multirow{2}{*}{$\begin{array}{l}\text { TG } \\
\text { type }\end{array}$} & \multicolumn{2}{|c|}{ SO } & \multicolumn{2}{|c|}{$\mathrm{CO}$} & \multicolumn{2}{|c|}{$\mathrm{L}$} & \multicolumn{2}{|c|}{$\mathrm{B}$} \\
\hline & Found & Calc. & Found & Calc. & Found & Calc. & Found & Calc. \\
\hline 36 & & & 1.6 & 0.4 & & & & \\
\hline 38 & & & 2.4 & 0.7 & & & & \\
\hline 40 & & & 3.6 & 2.1 & & & & \\
\hline 42 & & & 5.9 & 3.7 & & & & \\
\hline 44 & 0.4 & 0.1 & 6.2 & 7.8 & 0.4 & 0.3 & 0.3 & 0.3 \\
\hline 46 & 0.9 & 0.5 & 8.4 & 14.0 & 1.1 & 1.0 & 1.2 & 1.5 \\
\hline 48 & 3.5 & 2.8 & 11.4 & 20.0 & 5.0 & 4.5 & 5.6 & 5.8 \\
\hline 50 & 15.1 & 12.6 & 15.1 & 15.7 & 19.5 & 18.7 & 20.1 & 18.8 \\
\hline 52 & 39.1 & 37.9 & 25.0 & 18.1 & 41.7 & 40.3 & 40.6 & 38.2 \\
\hline 54 & 41.0 & 43.2 & 20.2 & 13.2 & 32.3 & 32.5 & 32.3 & 31.0 \\
\hline
\end{tabular}

* Determined by direct gas-liquid chromatography of triacylglycerol

** Calculated by means of 1-random, 2-random, 3-random distribution

*** Total number of acyl carbon atoms.

Other abbreviations used are the same as those described in Table 1. 
random distribution came to a considerbly good agreement on the thigh and breast muscle lipids from soybean oil, lard and beef tallow groups. But some discrepancies were observed among the values obtained from different methods on muscle $T G$ from coconut oil group. The experimental values for $\mathrm{C}_{46}$ and $\mathrm{C}_{48}$ components of muscle lipids, in both thigh and breast, were lower than the predicted values, and the experimental values for the $\mathrm{C}_{52}$ and $\mathrm{C}_{54}$ components are higher than the predicted values. on the muscle TG from coconut oil group.

The findings mentioned above suggest that a 1-random, 2-random, 3-random distribution of fatty acids in TG molecule in relation to those chain lengths occurred in the course of TG synthesis in muscle tissues on the feeding of soybean oil, lard and beef tallow. But, on the feeding of coconut oil, there is preferential synthesis of the $\mathrm{C}_{52}$ and $\mathrm{C}_{54}$ components, i.e. $16,18,18-\mathrm{TG}$ and $18,18,18-\mathrm{TG}$, in relation to that for the $\mathrm{TG}$ of $\mathrm{C}_{48}$ component.

Effects of dietary treatments of laying hen on the muscle $T G$ species based on degree of unsaturation

The TG was separated into simpler molecular species by $\mathrm{AgNO}_{3}-\mathrm{TLC}$ on the basis of total number and distribution of double bonds per molecule. The results are shown in Fig. 3 .

Usually nine or more bands of TG species were detected on the plates. Some of those TG were separated in individual bands, but for the instance, the mixture of $\mathrm{TG}$ species of $\mathrm{S}_{2} \mathrm{D}$ and $M_{3}$, and sometimes the mixture of $M_{3}$ and SMD were obtained as a single band on the chromatogram as pointed out by CHRISTIE and Moore previously ${ }^{26)}$. In such case, the composition of those bands that contain mixture of TG species were calculated on the basis of their fatty acid compositions ${ }^{27)}$. The results of quantitative analysis on TG components of thigh and breast nuscle lipids from each dietary group are shown in Table 7 .

The muscle lipid from soybean oil group contained less amounts of TG comprising monoenoic acids $\left(\mathrm{S}_{2} \mathrm{M}\right.$ and $\left.\mathrm{SM}_{2}\right)$, and more of TG comprising dienoic or trienoic acids $\left(\mathrm{M}_{2} \mathrm{D}\right.$, $\mathrm{SD}_{2}$, SMT and $\mathrm{D}_{3}$ ) than those from the other groups, while lipid from coconut oil group had most amounts of $\mathrm{S}_{3}$ and $\mathrm{S}_{2} \mathrm{M}$ species among the dietary groups. Although the thigh muscle lipids from both lard and beef tallow groups

Table 7 Triacylglycerol types of chicken muscle lipids from hens fed fat-supplemented diets

(mole \%)

\begin{tabular}{|c|c|c|c|c|c|c|c|c|}
\hline \multirow{2}{*}{$\begin{array}{l}\mathrm{TG}^{*} \\
\text { type }\end{array}$} & \multicolumn{4}{|c|}{ Thigh muscle } & \multicolumn{4}{|c|}{ Breast muscle } \\
\hline & SO & $\mathrm{CO}$ & $\mathrm{L}$ & $\mathrm{B}$ & SO & $\mathrm{CO}$ & $\mathrm{L}$ & $\mathrm{B}$ \\
\hline $\mathrm{S}_{3}$ & 2.5 & 12.7 & 3.4 & 3.9 & 2.6 & 13.9 & 4.1 & 4.0 \\
\hline $\mathrm{S}_{2} \mathrm{M}$ & 10.5 & 28.1 & 15.3 & 18.8 & 10.3 & 23.2 & 17.0 & 16.6 \\
\hline $\mathrm{SM}_{2}$ & 14.7 & 17.4 & 23.0 & 23.7 & 13.6 & 15.8 & 22.4 & 26.0 \\
\hline $\mathrm{S}_{2} \mathrm{D}$ & 8.7 & 7.9 & 6.7 & 5.7 & 6.0 & 9.0 & 7.0 & 6.9 \\
\hline $\mathrm{M}_{3}$ & 8.6 & 6.9 & 16.5 & 15.9 & 6.4 & 6.8 & 12.2 & 10.9 \\
\hline SMD & 19.5 & 17.7 & 22.6 & 19.3 & 19.5 & 17.6 & 18.7 & 16.3 \\
\hline $\mathrm{M}_{2} \mathrm{D}$ & 11.5 & 5.4 & 8.3 & 8.1 & 11.7 & 7.5 & 12.1 & 12.5 \\
\hline $\mathrm{SD}_{2}$ & 8.2 & 2.4 & 2.7 & 1.8 & 8.7 & 3.5 & 3.0 & 2.5 \\
\hline $\mathrm{S}_{2} \mathrm{~T}$ & 2.2 & 1.3 & 1.2 & 1.5 & 1.2 & 1.7 & 1.7 & 1.6 \\
\hline $\mathrm{MD}_{2}$ & 6.7 & & 0.1 & 1.0 & 8.6 & 0.4 & 1.2 & 2.1 \\
\hline SMT & 3.2 & 0.2 & 0.2 & 0.3 & 5.7 & 0.7 & 0.6 & 0.6 \\
\hline $\mathrm{D}_{3}$ & 3.4 & & & & 5.2 & & & \\
\hline SDT & 0.3 & & & & 0.5 & & & \\
\hline
\end{tabular}

* $\mathrm{S}=$ Saturated, $\mathrm{M}=$ monoenoic, $\mathrm{D}=$ dienoic and $\mathrm{T}=$ trienoic fatty acid. Other abbreviations used are the same as those described in Table 1. 
Table 8 Comparison of observed and predicted values of triacylglycerols of chicken muscle lipids (mole $\not 6$ )

\begin{tabular}{|c|c|c|c|c|c|}
\hline \multirow{2}{*}{\multicolumn{2}{|c|}{ TG type* }} & \multicolumn{4}{|c|}{ Thigh muscle } \\
\hline & & SO & $\mathrm{CO}$ & $\mathrm{L}$ & $\mathrm{B}$ \\
\hline \multirow{2}{*}{$\mathrm{S}_{3}$} & Found & 2.5 & 12.7 & 3.4 & 3.9 \\
\hline & Calc. & 1.8 & 13.5 & 3.2 & 4.2 \\
\hline \multirow{2}{*}{$\mathrm{S}_{2} \mathrm{U}$} & Found & 21.4 & 37.3 & 23.2 & 26.0 \\
\hline & Calc. & 16.2 & 39.7 & 21.1 & 24.4 \\
\hline \multirow{2}{*}{$\mathrm{SU}_{2}$} & Found & 45.9 & 37.7 & 48.5 & 45.1 \\
\hline & Calc. & 35.0 & 36.2 & 44.9 & 45.0 \\
\hline \multirow{2}{*}{$\mathrm{U}_{3}$} & Found & 29.2 & 12.3 & 24.5 & 24.9 \\
\hline & Calc. & 37.0 & 10.5 & 31.2 & 27.1 \\
\hline \multirow{2}{*}{\multicolumn{2}{|c|}{ TG type* }} & \multicolumn{4}{|c|}{ Breast musele } \\
\hline & & SO & $\mathrm{CO}$ & $\mathrm{L}$ & $\mathrm{B}$ \\
\hline \multirow{2}{*}{$\mathrm{S}_{3}$} & Found & 2.6 & 13.9 & 4.1 & 4.0 \\
\hline & Calc. & 1.8 & 12.4 & 3.9 & 4.4 \\
\hline \multirow{2}{*}{$\mathrm{S}_{2} \mathrm{U}$} & Found & 17.5 & 33.9 & 25.7 & 25.1 \\
\hline & Calc. & 15.7 & 38.5 & 23.3 & 24.8 \\
\hline \multirow{2}{*}{$\mathrm{SU}_{2}$} & Found & 48.0 & 37.6 & 44.7 & 45.4 \\
\hline & Calc. & 44.1 & 38.0 & 45.4 & 44.7 \\
\hline \multirow{2}{*}{$\mathrm{U}_{3}$} & Found & 31.9 & 14.7 & 25.5 & 25.5 \\
\hline & Calc. & 39.1 & 12.1 & 28.9 & 26.2 \\
\hline
\end{tabular}

${ }^{*} \mathrm{~S}=$ Saturated and $\mathrm{U}=$ unsaturated fatty acid Other abbreviations used are the same as those described in Table 1.

had more $M_{3}$ and SMD species and less $M_{2} D$ than the breast muscle lipids from each corresponding dietary group, the muscle TG from both groups showed comparatively similar values in each TG species in each muscle tissue.

Table 8 compares the values of TG species found by $\mathrm{AgNO}_{3}$-TLC with those calculated by a 1-random, 2-random, 3-random distribution of fatty acids in TG of muscle lipids from each dietary group.

Considerable good agreements were observed between the actual and predicted values in muscle lipids from coconut oil, lard and tallow groups, except $U_{3}$ species of the thigh muscle from lard group. In the muscle lipids from soybean oil group, some differences between determined and calculated values were observed in TG of $\mathrm{SU}_{2}$ and $\mathrm{U}_{3}$ species. This findings that the experimental values were higher for
$\mathrm{TG}$ of $\mathrm{SU}_{2}$ and lower for $\mathrm{U}_{3}$ than the random values suggest the preferential synthesis of the diunsaturated $\mathrm{TG}$ in relation to that of the triunsaturated TG in the laying hens on feeding of soybean oil-supplemented diet.

\section{References}

1) Katz, M.A., Dugan, L.R.Jr., and DawSon, L.E. : J. Food Sci., 31, 717 (1966).

2) MARION, J.E. and WoOdROoF, J.G.: $J$. Food Sci., 30, 38 (1965).

3) Saharabudhe, M.R., Delorme, N.F. and Wood, D.F. : Poultry Sci., 64, 910 (1985).

4) Jantawat, P. and Dowson, L.E. : Poultry Sci., 59, 1043 (1980).

5) Marion, J.E. and Miller, W.O. : Poultry Sci., 47, 1453 (1968).

6) MARION, J.E. and WoOdroof, J.G. : Poultry Sci., 42, 1202 (1963).

7) SCHuler, G.A. and Essary, E.O. : J. Food Sci., 36, 431 (1971).

8) Chung, R.A., Davis, E.Y., Munday, R.A. and TSAO, L.C.: Poultry Sci., 46, 133 (1967).

9) Miller, D. and Robisch, P. : Poultry Sci., 48, 2146 (1969).

10) Hirata, A., Nishino, M., Kimura, T. and Oнtake, Y.: Nippon Shokuhin Kogyo Gakkaishi, 33, 480 (1986).

11) Hirata, A., Nishino, M., Kimura, T. and OhtaKe, Y.: Nippon Shokuhin Kogyo Gakkaishi, 33, 631 (1986).

12) Isaacks, R.E., Davis, R.E., Ferguson, T.M., REISER, R. and Couch, J.R.: Poultry Sci., 43, 105 (1964).

13) Christie, W.W. and Moore, J.H. : Lipids, 5, 921 (1970).

14) Hirata, A., Nishino, M., Kimura, T. and OHtake, Y.: Nippon Shokuhin Kogyo Gakkaishi, 32, 892 (1985).

15) FolCh, J., Leas, N. and Stanley, G.H.S. : J. Biol. Chem., 226, 497 (1957).

16) MoERCK, K.E., and BALL, H.R. Jr.: J. Food Sci., 38, 978 (1973).

17) BrockerhoFf, H. : J. Lipid Res., 6, 10 (1965).

18) Christie, W.W. and MoORe, J.H.: Biochim. Biophys. Acta, 176, 445 (1969).

19) Hirata, A., Masuda, T., Kimura, T. and OHTAKe, Y.: Nippon Shokuhin Kogyo Gakkaishi, 34, 320 (1987).

20) Wood, R. and SNYder, F.: J. Am. Oil 
Chem. Soc., 43, 53 (1966).

21) Christie,. W.W. and Moore, J.H.: Biochim. Biophys. Acta, 210, 46 (1970).

22) OHTAKe, Y.: Jap. J. Zootech. Sci., 54, 179 (1983).

23) Kuksis, A., McCarthy, M.J. and Beverige, J.M.R. : J. Am. Oil Chem. Soc., 40, 530 (1963).

24) Ohtake, Y.: Jap. J. Zootech. Sci., 53, 797 (1982).

25) Marion, J.E., Boggers, T.S.Jr.. and WoODRoOF, J.G.: J. Food Sci., 32, 426. (1967).

26) Christie, W.W. and Moore, J.H. : Lipids, 4, 345 (1969).

27) Blank, M.L., Verdino, B. and PrivetT, O.S. : J. Am. Oil Chem. Soc., 42, 87 (1965). (Received Mar, 13, 1987)

\section{産畉鵙筋肉脂質のトリアシルグリセロールの 組成ならびに構造に及ぼす 饲料油脂の影響}

平田明弘 ${ }^{*}$ ・堌田哲也 ${ }^{*} \cdot$ 木村貞司 ${ }^{*}$ 大武由之*

( ${ }^{*}$ 日本大学農獣医学部 †154 東京都世田谷区下馬 $3-$ 34-1)

産卵鶏筋肉脂質のトリアシルグリセロール（TG）の 組成と構造に及ぼす飼料油脂（大豆油，ココヤシ油，ラ
ードおよび牛脂）の影響を調べた，各飼料区の筋肉総脂 質の脂肪酸組成は，飼料に加えた油脂の組成を反映して いた，腿肉および胸箭の TG を立体特暴的分析に付し た。一般に $\mathrm{C}_{16: 0}, \mathrm{C}_{16: 1}, \mathrm{C}_{18: 0}$ は TGの sn-1 およひ sn-3 位置に優先的にエステル化していた．C18:1はsn-3 位置に多く，C18:2 はsn-2 位置に多く結合していた。 高温ガスクロマトグラフィーにより，炭素数に基づき TG を分別した，大豆油区，ラード区および牛脂区の脂質は， 共に $\mathrm{C}_{50}, \mathrm{C}_{52}$ ならびに $\mathrm{C}_{54}$ を主要な $\mathrm{TG}$ 成分とし、コ コヤシ油区の脂質は, $\mathrm{C}_{50} \sim \mathrm{C}_{54}$ に加えて中鎖炭素数の $\mathrm{C}_{34} \sim \mathrm{C}_{48}$ の TG 成分老く有していた, 硝酸銀付加 薄層クロマトグラフィーによって，不飽和度に基いて TG 分子種を分画した，大豆油区の脂質は，他の飼料区の脂 質よりむ $\mathrm{S}_{2} \mathrm{M}$ や $\mathrm{SM}_{2}$ が少なく, $\mathrm{M}_{2} \mathrm{D}, \mathrm{SD}_{2}, \mathrm{MD}_{2}$, $\mathrm{SMT}$ および $\mathrm{D}_{3}$ 成分が多かった，これに対してココヤ シ油区の脂質は，飼料区のなかでは $\mathrm{S}_{3}$ と $\mathrm{S}_{2} \mathrm{M}$ 成分が 最も多かった，TG 分子種の実測值と，TG内で脂肪酸 の 1-ランダム，2-ランダム，3-ランダム配置を仮定し て求めた計算值との比較を行った。 ラード区と牛脂区の 筋肉脂質にあっては，比較的良く一致していたが，大豆 油区やココヤシ油区の脂質では，相違の認められるとこ ろがあったここのことは，拱取した飼料脂肪酸に影響さ れ，産卵鶏では TG の生合成にあたって，ある種の夕 イプの TG 分子種の優先的な合成も行われることを示 唆している。 